EDUARDO ROCKENBACH PIRES

\title{
A CONCILIAÇÃO NO DIREITO DO TRABALHO BRASILEIRO: DO DISCURSO DA IRRENUNCIABILIDADE AO RISCO DA PRECARIZAÇÃO HOMOLOGADA
}


EDUARDO ROCKENBACH PIRES

\title{
A CONCILIAÇÃO NO DIREITO DO TRABALHO BRASILEIRO: DO DISCURSO DA IRRENUNCIABILIDADE AO RISCO DA PRECARIZAÇÃO HOMOLOGADA
}

\begin{abstract}
Tese apresentada à banca examinadora do Programa de Pós-Graduação em Direito, da Faculdade de Direito da Universidade de São Paulo, como exigência parcial para obtenção do título de Doutor em Direito, na área de concentração Direito do Trabalho e da Seguridade Social, sob a orientação do Professor Associado Paulo Eduardo Vieira de Oliveira.
\end{abstract}





\section{FOLHA DE AVALIAÇÃO}

Eduardo Rockenbach Pires

A conciliação no direito do trabalho brasileiro: do discurso da irrenunciabilidade ao risco da precarização homologada

Tese apresentada à banca examinadora do Programa de Pós-Graduação em Direito, da Faculdade de Direito da Universidade de São Paulo, como exigência parcial para obtenção do título de Doutor em Direito, na área de concentração Direito do Trabalho e da Seguridade Social, sob a orientação do Professor Associado Paulo Eduardo Vieira de Oliveira.

Aprovado em

Banca examinadora:

Professor:

Assinatura:

Professor:

Assinatura:

Professor:

Assinatura

Professor:

Assinatura:

Professor:

Assinatura:

Professor:

Assinatura: 



\section{AGRADECIMENTOS}

Eu tenho muito pelo que agradecer, ao concluir um trabalho como este. Não haveria como inserir um texto neste espaço que abrangesse toda essa gratidão (essa tarefa, acredite, exigiria um

livro à parte), mas, mesmo assim, deixo aqui uma síntese de meu sentimento neste momento.

Em primeiro lugar, agradeço muito à minha família: minha mãe,

Vera; meu pai, Edmundo; minha irmã, Cíntia; e meu irmão, André; sempre recebi deles o apoio e o estímulo necessários à busca de realização de meus projetos.

Muitos amigos mereceriam menção individualizada aqui, mais do que o espaço comporta. Amigos de muitos anos, de infância, de adolescência; amigos da juventude; parceiros da magistratura

e da docência; companheiros de faculdade e companheiros da pós-graduação. Agradeço a todos que me auxiliaram nessa luta, cada um à sua maneira, muitas vezes sem ter a exata noção da importância da ajuda que me ofereciam.

Tenho muito a agradecer aos professores, a todos os professores que tive, pelos ensinamentos e estímulos que me trouxeram até aqui. Do ensino fundamental, do ensino médio, dos cursos preparatórios, da graduação e da pós-graduação. Muitos mestres me vêm à memória hoje, e sinto profunda gratidão.

Especialmente, meus agradecimentos e minha admiração aos grandes professores da Faculdade de Direito da USP, em especial ao professor Paulo Eduardo, meu orientador, que confiou em meus projetos de mestrado e de doutorado, e soube compreender as dificuldades pelas quais passei nestes últimos anos.

Gostaria de registrar meus sinceros agradecimentos aos servidores da biblioteca do Tribunal Regional do Trabalho da $2^{\mathrm{a}}$ Região, a todos na pessoa da incansável Denise.

Agradeço também aos trabalhadores e às trabalhadoras do país. Devo toda minha formação à educação pública: cursei o ensino fundamental em escolas estaduais e municipais no Rio Grande do Sul; o ensino médio em escola estadual, no Mato Grosso do

Sul, onde também cursei a graduação em Direito, na universidade federal (UFMS). O mestrado e, agora, o doutorado 
foram feitos na USP, uma universidade estadual. Em todas essas instituições, tive acesso à educação gratuita, em verdade custeada pela sociedade como um todo, por meio de tributos. A injustiça do sistema tributário brasileiro faz com que as classes de renda mais baixa sofram com contribuições proporcionalmente mais pesadas, e por isso não posso ignorar o fato de que muitas trabalhadoras e trabalhadores, com pouca ou nenhuma instrução formal, têm participação decisiva no custeio da educação pública, em benefício de pessoas como eu. Nada mais justo que algum benefício seja proporcionado pela educação pública a essas pessoas. A universidade, a pesquisa e a ciência devem ser independentes do poder econômico, por essa razão, entre outras mais.

Preciso externar meus agradecimentos aos músicos. A todos: creio que, sem música, a vida não seria possível. A Humberto Gessinger, agradeço especialmente por ter escrito uma letra cujo verso diz: "não vim até aqui pra desistir agora!"

Por fim, quero agradecer à minha "turminha": à Lia, companheira de todos os momentos, que me incentivou muito em todas as fases deste trabalho; à minha filha Sofia, com quem tenho uma relação de ensino e aprendizado em mão dupla; e ao pequeno Marcelo, que nasceu na mesma época do nascimento desta pesquisa. Por mais que eu me esforce, não consigo capturar palavras adequadas e arranjá-las de modo a construir uma frase de agradecimento suficientemente eficaz para expressar a importância que vocês têm para mim. Impossível traduzir em palavras a alegria, os sorrisos, as tristezas, os desafios, os planos, as esperanças, os abraços e os beijos que formam o rico colorido do nosso mundo. Mesmo aqui, escrevendo, a emoção me traz um nó na garganta e as lágrimas me nublam o olhar. Só consigo dizer isto: muito obrigado! Para 
Vieste ao mundo prematuramente, perigosamente, Foste bravo e forte, apesar de pequeno e frágil. Deste-nos uma aula de como lutar pela vida! Secaste minhas lágrimas, as de tua mãe e as de tua irmã. E hoje, Marcelo, teu riso inunda a existência. 



\section{RESUMO}

PIRES, Eduardo Rockenbach. A conciliação no direito do trabalho brasileiro: do discurso da irrenunciabilidade ao risco da precarização homologada. $191 \mathrm{p}$. Tese de Doutorado. Faculdade de Direito da Universidade de São Paulo: São Paulo 2018.

O trabalho tem o objetivo de estudar o regime jurídico da conciliação realizada no âmbito do direito do trabalho e suas implicações no tocante à integridade dos direitos dos trabalhadores. Aborda os problemas derivados da crise do Poder Judiciário brasileiro, cujo conteúdo é basicamente a demora dos julgamentos, em razão do excesso de processos em tramitação. Analisa características do movimento pela conciliação, como política pública judiciária para o enfrentamento da crise, notadamente a influência quanto à jurisdição trabalhista no Brasil. Recorda e analisa a tradição da Justiça do Trabalho brasileira quanto à valorização da solução conciliada dos litígios. Aborda a conciliação pela ótica da celeridade e da efetividade da tutela jurisdicional. Recupera aspectos históricos da Justiça do Trabalho e da afirmação dos direitos trabalhistas no Brasil. Analisa aspectos da dinâmica forense quanto à prática da conciliação. Salienta vantagens jurídicas e econômicas conferidas pela conciliação aos empregadores. Aborda o princípio da irrenunciabilidade dos direitos trabalhistas e a função do direito do trabalho no capitalismo. Indica pontos da reforma da lei trabalhista brasileira que tenham relação com a conciliação. Propõe estudo da forma jurídica e da forma política para a compreensão da conciliação no processo do trabalho. Revela aspectos ideológicos da conciliação trabalhista e suas influências.

\section{Palavras-chave:}

Direito. Trabalho. Conciliação. Processo. Ideologia. Estado. 



\begin{abstract}
PIRES, Eduardo Rockenbach. The conciliation in Brazilian labor law: from the discourse of protection to the risk of precariousness homologated. 191 p. Doctoral thesis. Faculdade de Direito da Universidade de São Paulo: São Paulo 2018.

The aim of this text is to study the legal regime of conciliation carried out in the field of labor law and its implications for the integrity of workers' rights. It addresses the problems arising from the crisis of the Brazilian Judiciary, whose content is basically the delay of the judgments, due to the excess of actions in process. It analyzes characteristics of the conciliation movement, as a public judicial policy to confront the crisis, notably the influence regarding labor jurisdiction in Brazil. It recalls and analyzes the tradition of the Brazilian Labor Justice regarding the valuation of the conciliated solution of the litigation. It addresses conciliation from the point of view of celerity and the effectiveness of judicial protection. It recovers historical aspects of Labor Justice and the affirmation of labor rights in Brazil. It analyzes aspects of the forensic dynamics regarding the practice of conciliation. It highlights legal and economic advantages conferred by conciliation to employers. It addresses the principle of the inalienability of labor rights and the role of labor law in capitalism. It indicates points of the reform of the Brazilian labor law that have relation with the conciliation. It proposes a study of the legal form and the political form for the understanding of conciliation in the labor process. It reveals ideological aspects of labor conciliation and its influences.
\end{abstract}

\title{
Keywords:
}

Law. Labor. Conciliation. Process. Ideology. State. 



\section{RIASSUNTO}

PIRES, Eduardo Rockenbach. La conciliazione nel diritto del lavoro brasiliano: dal discorso di protezione al rischio di precarietà omologata. $191 \mathrm{p}$. Tesi di dottorato. Faculdade de Direito da Universidade de São Paulo: São Paulo 2018.

Lo scopo di questo testo è quello di studiare il regime giuridico di conciliazione attuato nel campo del diritto del lavoro e le sue implicazioni per l'integrità dei diritti dei lavoratori. Affronta i problemi derivanti dalla crisi della giustizia brasiliana, il cui contenuto è sostanzialmente il ritardo dei giudizi, a causa dell'eccesso di processi in corso. Analizza le caratteristiche del movimento di conciliazione, come una politica giudiziaria pubblica per affrontare la crisi, in particolare l'influenza sulla giurisdizione del lavoro in Brasile. Richiama e analizza la tradizione della giustizia del lavoro brasiliana in merito alla valutazione della soluzione conciliativa del contenzioso. Affronta la conciliazione dal punto di vista della celerità e dell'efficacia della tutela giudiziaria. Recupera gli aspetti storici della giustizia del lavoro e l'affermazione dei diritti del lavoro in Brasile. Analizza aspetti delle dinamiche forensi riguardanti la pratica della conciliazione. Evidenzia i vantaggi legali ed economici conferiti dalla conciliazione con le aziende. Affronta il principio dell'inalienabilità dei diritti del lavoro e il ruolo del diritto del lavoro nel capitalismo. Indica punti della riforma del diritto del lavoro brasiliano che hanno relazione con la conciliazione. Propone uno studio della forma giuridica e della forma politica per la comprensione della conciliazione nel processo lavorativo. Rivela gli aspetti ideologici della conciliazione e le sue influenze.

\section{Parole chiave:}

Diritto. Lavoro. Conciliazione. Processo. Ideologia. Stato. 



\section{SUMÁRIO}

1. Considerações iniciais $\ldots \ldots \ldots \ldots \ldots \ldots \ldots \ldots \ldots \ldots \ldots \ldots \ldots \ldots \ldots \ldots \ldots \ldots$

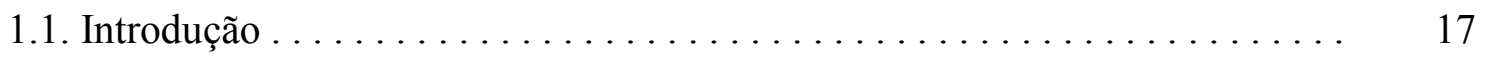

1.2. O tema, suas limitações e justificativas . . . . . . . . . . 21

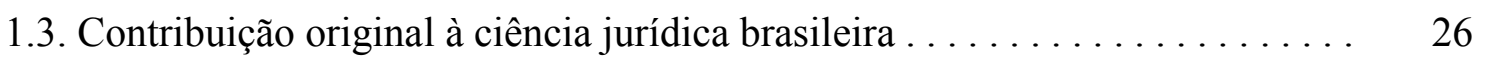

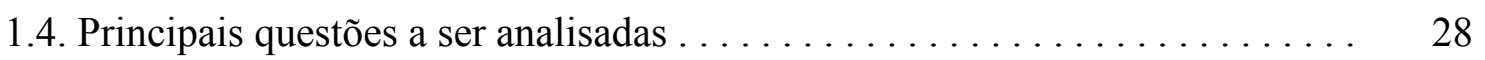

2. A crise do Poder Judiciário Nacional e a política pública de conciliação . . 31

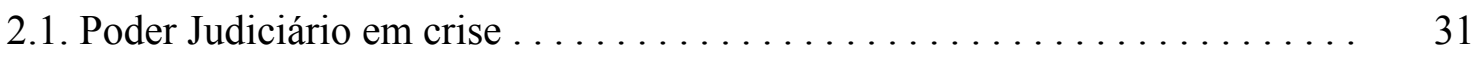

2.2. A ideia de sociedade beligerante $\ldots \ldots \ldots \ldots \ldots \ldots \ldots \ldots \ldots \ldots \ldots \ldots \ldots \ldots$

2.3. Movimento Nacional pela Conciliação . . . . . . . . . . . . . . . 47

2.4. Conciliação e crise na Justiça do Trabalho . . . . . . . . . . . . . . 57

3. Conciliação e direito do trabalho no Brasil .................. 61

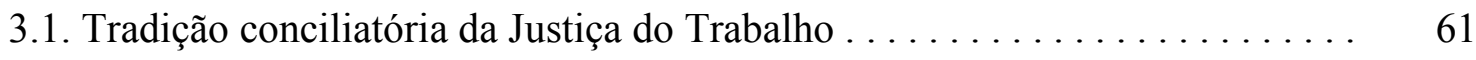

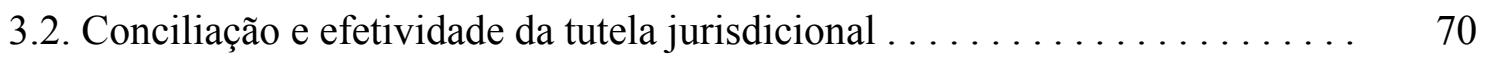

3.3. Afirmação dos direitos trabalhistas no Brasil: "função oculta" da conciliação 77

3.4. Processo do trabalho real: a conciliação em movimento . . . . . . . . . . . . . 89

4. Contradições dogmáticas da conciliação trabalhista $\ldots \ldots \ldots \ldots \ldots \ldots \ldots \quad 98$

4.1. A irrenunciabilidade dos direitos trabalhistas . . . . . . . . . . . . . 98

4.2. O direito do trabalho como limite da exploração capitalista . . . . . . . . 111

4.3. Conciliação e volume de processos: o fim que não justifica o meio . . . . . . 120

4.4. Uma reforma inesperada . . . . . . . . . . . . . . . . . . 125

5. Essência da conciliação trabalhista: para além dos discursos . . . . . . . 135

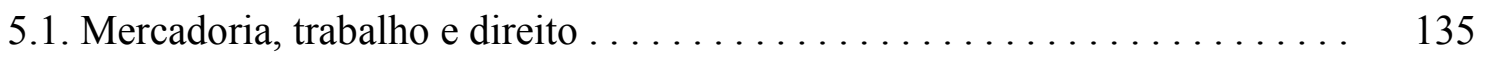


5.2. O Estado no contexto da conciliação trabalhista . . . . . . . . . . . . . 152

5.3. Aspectos ideológicos da conciliação trabalhista . . . . . . . . . . . . . 157

5.4. A precarização homologada . . . . . . . . . . . . . . . . . . . . 167

6. Considerações finais $\ldots \ldots \ldots \ldots \ldots \ldots \ldots \ldots \ldots \ldots \ldots \ldots \ldots \ldots \ldots, 175$

Referências bibliográficas ........................... 179 


\section{Considerações iniciais}

\subsection{Introdução}

JUIZ - Sr. Escrivão, faça o favor de ler.

ESCRIVÃO - (lendo) - diz Inácio José, natural desta freguesia e casado com Josefa Joaquina, sua mulher na face da Igreja, que precisa que Vossa Senhoria mande a Gregório degradado para fora da terra, pois teve o atrevimento de dar uma embigada em sua mulher, na encruzilhada do PauGrande, que quase a fez abortar, da qual embigada fez cair a dita sua mulher de pernas para o ar. Portanto pede a Vossa Senhoria mande o dito Gregório degradado para Angola, E.R.N.

JUIZ - É verdade, Sr. Gregório, que o senhor deu uma embigada na senhora? GREGÓRIO - É mentira, Sr. Juiz de paz, eu não dou embigada em bruxas.

JOSEFA JOAQUINA - Bruxa é a marafona de tua mulher, malcriado! Já não me lembra que me deu uma embigada, e que me deixou uma marca roxa na barriga? Se o senhor quer ver, posso mostrar.

JUIZ - Nada, nada, não é preciso; eu o creio.

JOSEFA JOAQUINA - Sr. Juiz, não é a primeira embigada que este homem me dá; eu é que não tenho querido contar a meu marido.

JUIZ - Está bom, senhora, sossega. Sr. Inácio José, deixa-se destas asneiras, dar embigadas não é crime classificado no Código. Sr. Gregório, faça o favor de não dar mais embigadas na senhora; quando não, arrumo-lhe com as leis às costas e meto-o na cadeia. Queira-se retirar.

INÁCIO JOSÉ E GREGÓRIO - Lá fora me pagarás.

JUIZ - Estão conciliados.

(INÁCIO JOSÉ, GREGÓRIO E JOSEFA JOAQUINA SAEM)

JUIZ - Sr. Escrivão, leia outro requerimento. ${ }^{1}$

O tema desta tese é a conciliação realizada no âmbito dos conflitos trabalhistas. Confesso que senti certo desconforto ao descobrir, logo nos primeiros estudos do direito do trabalho e do processo do trabalho, que era na seara trabalhista que se conferia mais valor às soluções dos litígios por conciliação. Pensava: "por que logo no direito do trabalho se busca com mais força a solução por acordo?” Não fazia sentido.

Não era no direito do trabalho que havia o princípio da proteção, do qual irradiava a irrenunciabilidade dos direitos dos trabalhadores? Então, como se poderia chegar no processo do trabalho e inserir a máxima valorização da negociação de

\footnotetext{
${ }^{1}$ Trecho da peça $O$ juiz de paz na roça, de Martins Pena (São Paulo: FTD, 2009).
} 
direitos? Por outro lado, no processo civil em geral esse discurso de valorização da conciliação sempre foi meio vazio, uma espécie de protocolo de intenções. Algo como “precisamos fazer como na Justiça do Trabalho, valorizar a conciliação!”, mas sem tanto resultado concreto.

Na Justiça do Trabalho, sim, era - e é, cada vez mais - importante conciliar. Diziam-me que os juízes do trabalho insistiam tanto nas tentativas de acordo que as partes às vezes ficavam constrangidas. Diziam também, pejorativamente, que a Justiça do Trabalho era um "balcão de negócios", um "mercado de peixe" e que, a rigor, nem era efetivamente uma justiça. Era "justicinha". Aliás, a frase completa dizia: "a Justiça do Trabalho não é justiça; o processo do trabalho não é processo; e o direito do trabalho não é direito". Nem era preciso estudar muito o tal direito do trabalho, aconselhavam, porque quando vamos à audiência tudo se resume à negociação de um acordo.

Aquilo não fazia sentido para mim - e, sinceramente, ainda não faz. $\mathrm{O}$ direito do trabalho (e, por extensão, o processo do trabalho e a Justiça do Trabalho) tem a missão de proteger direitos fundamentais dos trabalhadores, que são pessoas fragilizadas nas relações com os empresários e, geralmente, em suas condições de vida também. As normas trabalhistas tutelam os interesses dos trabalhadores, tentando equilibrar juridicamente uma situação que, econômica e socialmente, caracteriza-se pela desigualdade.

Então, pensava eu - e, sinceramente, ainda penso - que, houvesse alguma área do direito que fosse propícia à máxima incidência da conciliação, seria o direito civil ou o direito empresarial. Não o direito do trabalho, que pouco espaço deveria deixar à autonomia da vontade. Mas não é assim. O processo civil, hoje em dia, tem um novo código de regência e ainda luta para que a conciliação seja elevada perante o conceito das partes e até mesmo dos advogados e juízes. E, na Justiça do Trabalho, a busca da conciliação se intensifica cada vez mais. Aliás, a cúpula do Poder Judiciário elegeu a conciliação como a grande cartada para enfrentar uma crise de excesso de processos e de consequente lentidão no funcionamento da justiça. Nem preciso ressaltar que é na Justiça do Trabalho que o protagonismo dessa campanha atinge seu ponto mais alto. 
Daí o interesse que me despertou o assunto. Afinal, o que representa toda essa campanha pela conciliação no direito do trabalho? Como compreender o acordo entre patrão e empregado (ou, pior ainda, entre empresário e desempregado), que tenha por objeto direitos trabalhistas básicos? Qual o contexto histórico e social dessa valorização da conciliação no direito do trabalho? A conciliação trabalhista é mesmo um instrumento de tutela da situação jurídica dos trabalhadores, ou, ao contrário, é um instrumento de supressão de seus direitos? Enfim, toda essa insistência na conciliação serve para o bem ou para o mal da classe trabalhadora ${ }^{2}$ ? Com tais perguntas iniciais, parti para um projeto de pesquisa, de cuja realização resultou este texto.

Apresento, portanto, à leitora ou ao leitor, os resultados da pesquisa.

Antes, contudo, de iniciar a exposição da tese propriamente dita, permitome consignar duas observações. Em primeiro lugar, uma justificativa quanto à linguagem utilizada neste trabalho. Opto, de maneira consciente, pelo discurso em primeira pessoa. Sem embargo das tradicionais recomendações de redação do texto científico de maneira puramente objetiva e impessoal - e obviamente sem com isso querer criticar quem a elas recorre em seus textos ${ }^{3}-$, convenci-me de que a linguagem jurídica neutra serve de instrumento de difusão da ideia de desconexão do direito em relação à realidade social, como se ele pairasse sobre a sociedade, como se ele viesse “de cima" (um aspecto do fenômeno jurídico que será analisado em tópico específico da tese). A linguagem impessoal tem uma contribuição decisiva nesse sentido. Escrevemos “entende-se" em vez de "entendo", "vê-se" no lugar de "vejo", “decide-se” no lugar de "decido", e com isso a impessoalidade exibida pelo verbo em voz passiva de certa forma mantém a separação do direito quanto à realidade concreta da sociedade; mantém-no como algo independente, separado da vida das pessoas reais. É como se ele não estivesse aqui, entre nós.

\footnotetext{
2 Entendida a expressão "classe trabalhadora" no sentido proposto por Ricardo Antunes, ou seja, incluindo "a totalidade daqueles que vendem sua força de trabalho, tendo como núcleo central os trabalhadores produtivos" (1999, p. 102).

${ }^{3}$ Ambas as formas encontram guarida nas recomendações de Umberto Eco (2007, p. 170).
} 
Não posso, ainda, deixar de reconhecer que o estilo e a fluência do texto são prejudicados pela insistência na construção das orações com o verbo em voz passiva. Admito que isso me gera certo incômodo. Ademais, é interessante que tal estilo neutro de redação, por outro lado, funcione como uma espécie de proteção ao próprio autor, pois ele redige segundo uma visão que só pode ser sua - uma visão pessoal, nesse sentido -, mas com uma aparência de objetividade extrema, como se enunciasse uma mera constatação do que está em sua frente, sem qualquer influência de elementos e preferências pessoais, ou de fatores políticos, econômicos e ideológicos. Amilton Bueno de Carvalho afirma, sobre essa característica da linguagem jurídica, que, “como regra, o pensador do direito, o doutrinador do direito, o que ousa escrever sobre o direito, tem uma tendência de não se identificar. Ele vem e conversa, expondo seu saber teórico, prático, ou o pseudo saber teórico, pseudo saber prático, como se ele tivesse caído do céu, ou seja, como se ele não tivesse história" (1998, p. 17).

É superada no âmbito das ciências sociais a concepção de neutralidade do observador $^{4}$. Este, inegavelmente, traz consigo suas características pessoais e visões de mundo, tanto no momento da pesquisa quanto no da redação, e não tem como se despojar delas. A redação neutra parece insistir em deslocar o polo emissor da comunicação, gerando a impressão de que a mensagem teria sido enviada de uma posição independente, acima das individualidades. O uso do discurso em primeira pessoa representa, por sua vez, um elemento de constante exposição do autor como sujeito de suas próprias falas. Minha opção neste trabalho foi a de assumir plenamente essa condição.

A segunda observação diz respeito à postura crítica que adoto na exposição da tese. Embora seja inerente ao avançar da ciência a submissão dos resultados das pesquisas a constantes análises críticas, às vezes percebo que a crítica teórica é lida como um desprestígio ao autor criticado. Gostaria, logo de início, de afastar qualquer

\footnotetext{
${ }^{4}$ Segundo propõe Hilton Japiassu, "não há ciência 'pura', 'autônoma' e 'neutra', como se fosse possível gozar do privilégio de não se sabe que 'imaculada concepção'. Espontaneamente, somo levados a crer que o cientista é um indivíduo cujo saber é inteiramente racional e objetivo, isento não somente das perturbações da subjetividade pessoal, mas também das influências sociais. Contudo, se o examinarmos em sua atividade real, em suas condições concretas de trabalho, constataremos que a razão científica não é imutável. Ela muda. É histórica. [...] Isso significa que, em matéria de ciência, não há objetividade absoluta. Também o cientista jamais pode dizer-se neutro, a não ser por ingenuidade ou por uma concepção mítica do que seja a ciência. [...] Se há objetividade na ciência, é no sentido em que o discurso científico não engaja, pelo menos diretamente, a situação existencial do cientista." (1975, p. 10-11).
} 
leitura desse jaez. No decorrer do trabalho, teço várias considerações sobre o mérito de políticas adotadas pela cúpula do Poder Judiciário, analiso circunstâncias em que ocorrem negociações e homologações de acordos, além de estabelecer em alguns pontos um diálogo com teorias e doutrinas sobre institutos importantes ao desenvolvimento da pesquisa. Em nenhum momento, todavia, deixo de lado o respeito devido às pessoas relacionadas aos objetos criticados. Seja explícita, seja implicitamente. No tocante a autores e pesquisadores, aliás, é preciso deixar claro que travar diálogos com as teorias anteriores não significa de nenhum modo desprestigiá-las. Pelo contrário, tal ato revela a importância atribuída a essas teorias, de modo que o avanço na matéria não pode ser alcançado senão com a crítica aos resultados já obtidos.

Não me é dado neste momento avaliar - nem teria condições de fazê-lo - se esta pesquisa traz alguma contribuição minimamente relevante para a ciência do direito. No entanto, admitindo por hipótese que eu tenha conseguido lançar o olhar em algum ponto além do que foi até agora produzido, terá sido com a contribuição decisiva dos "gigantes" sobre cujos ombros eu pude me apoiar".

\subsection{O tema, suas limitações e justificativas}

A pesquisa que ora apresento tem como tema a conciliação judicial no âmbito do direito do trabalho individual brasileiro. Partindo das características do direito do trabalho e de suas peculiaridades no Brasil, procurei realizar uma análise sobre o fenômeno da conciliação como protagonista das formas de tutela jurisdicional trabalhista em voga no país.

Não é de hoje que a conciliação se caracteriza como técnica relevante da aplicação do direito do trabalho e do processo do trabalho. Desde os primórdios do surgimento da Justiça do Trabalho no Brasil, na primeira metade do século XX, ela é

\footnotetext{
${ }^{5}$ Lanço mão, aqui, da conhecida ideia subjacente à expressão atribuída a Isaac Newton, que teria dito "se eu pude ver mais longe, foi por estar nos ombros de gigantes". Virgílio Afonso da Silva explica, a propósito, que a ideia em si "é bem anterior a Newton, e costuma ser atribuída a John of Salisbury, nos seguintes termos: 'Nós somos como anões sentados no ombro de gigantes. Nós vemos mais - e coisas que estão mais distantes - que eles, não porque nossa visão é superior ou porque somos mais altos que eles, mas porque eles nos engrandecem, já que sua grande estatura soma-se à nossa'.” (2010, p. 29, nota 23).
} 
marcada pela nítida "vocação" para a busca da solução conciliada do litígio. Não é por coincidência que a nomenclatura original de suas unidades básicas era a de "Junta de Conciliação e Julgamento", justamente para acentuar a relevância da busca da conciliação nos conflitos trabalhistas. Ao juiz do Trabalho, aparentemente mais do que a qualquer outro juiz, cabia (e cabe) envidar esforços para instar os litigantes ao diálogo e à construção negociada da solução da causa - a sentença, ou solução heterônoma, seria uma técnica residual de solução. É sintomático que apenas no fim do século as juntas tenham passado à denominação de Varas do Trabalho, juntamente com a extinção da representação classista na Justiça do Trabalho, por força da Emenda Constitucional 24/1999.

Desde o início deste século XXI, entretanto, a conciliação recebeu uma carga extraordinária de valorização no Poder Judiciário brasileiro. Essa supervalorização surge no contexto da luta contra a grave crise que assola o Judiciário como um todo (não apenas a Justiça do Trabalho), em relação principalmente à lentidão da tramitação dos processos. A conciliação foi eleita, assim, como o fator de aceleração da resolução dos litígios. Aliás, é notória a influência do desempenho da Justiça do Trabalho (considerada mais célere e eficiente entre os ramos do Judiciário) na acolhida ampla desse instrumento pela justiça brasileira. O Conselho Nacional de Justiça (CNJ) passou a instituir campanhas de valorização da conciliação como meio de solucionar litígios, em todas - ou quase todas - as esferas judiciárias.

Como efeito dessa supervalorização, o direito do trabalho recebeu um influxo avassalador. A Justiça do Trabalho é a principal responsável pelos números eloquentes divulgados como resultado das campanhas do Movimento Nacional pela Conciliação. As já tradicionais "semanas de conciliação" envolvem juízes do Trabalho e servidores da Justiça do Trabalho do país inteiro para envidar esforços na tentativa de resolver o máximo de processos por meio da conciliação. Não raro, são divulgadas classificações dos tribunais em relação aos resultados obtidos e atualmente se vê, inclusive, nas páginas dos tribunais na internet, uma espécie de marcador digital em tempo real, que exibe as quantias "arrecadadas", por assim dizer, por meio de acordos homologados ${ }^{6}$.

6 Trata-se do assim chamado "conciliômetro". Sobre ele, cf.: http://www.cnj.jus.br/atosadministrativos/8164:conciliometro-indica-numero-de-acordos-firmados 
O despertar do interesse para o início da pesquisa decorreu da preocupação com uma certa banalização da conciliação no direito do trabalho. O estímulo, aparentemente excessivo, à busca das soluções conciliadas parece esconder uma violação à indisponibilidade que caracteriza em essência os direitos dos trabalhadores. Afinal, ainda é a irrenunciabilidade um dos princípios fundamentais do direito do trabalho - resisto a encerrar este período bem aqui, com um ponto de interrogação -, e o princípio da irrenunciabilidade não é, prima facie, lembrado no cotidiano do foro, em que vemos esforços às vezes desmedidos em busca da conciliação das partes, mesmo que em patamar inferior ao mínimo garantido socialmente ao trabalhador.

Não há negar a importância e a conveniência da conciliação como meio de solução de litígios, em especial naqueles que são mais afetos, por sua natureza e pela disponibilidade dos direitos envolvidos, à solução dialogada. Conflitos envolvendo pessoas jurídicas com relação a matérias de direito empresarial, por exemplo, podem e devem receber todos os esforços para a solução negociada entre as partes. Muitos litígios de direito de família também requerem esforços conciliatórios. Neste trabalho, todavia, o tema da pesquisa é restrito ao direito do trabalho e suas peculiaridades.

Um dos principais pontos de preocupação é o potencial coletivo dos conflitos trabalhistas. A solução de um processo individual, de um empregado ou exempregado, tem potencial eficácia nas relações dos demais empregados com o mesmo empregador. Comparecem à Justiça do Trabalho empresas que são litigantes habituais e contam, visivelmente, com as múltiplas possibilidades de resolver o processo mediante transação. Porém, o que se observa é que as concessões, via de regra, não são recíprocas (como exige o art. 840 do Código Civil), mas apenas da parte do trabalhador, premido pela necessidade de satisfação rápida, mesmo que não integral, de seu direito ${ }^{7}$. A repetição desse tipo de solução pode levar o empresário a buscar, de fato, uma redução

\footnotetext{
7 "Rotineiros são, em sede do processo do trabalho, os acordos por valor inferior ao da liquidação, no curso das execuções, o que revela que o tempo está distribuído de forma não equânime, incentivando o abandono de direitos, para que o resultado efetivo - isto é, a entrega real do bem da vida disputado pelos litigantes - seja alcançado mediante renúncia de dada parcela dos valores em disputa, como franca demonstração do desespero do autor.” (FAVA, 2009, p. 51).
} 
de custos com base na atuação conciliatória da Justiça do Trabalho. E isso em prejuízo da integridade do direito do trabalho.

Daí a ideia de estudar o fenômeno da conciliação no direito do trabalho pela ótica do princípio da irrenunciabilidade e da lógica da proteção juslaboral. A partir de questões como o que representa a conciliação na seara da Justiça do Trabalho, como ela vem sendo praticada, e ainda se existe uma forma de corrigir eventuais erros de curso no uso desse instrumento de pacificação.

O cenário brasileiro dos últimos anos é de extrema valorização da conciliação como técnica de solução de litígios e, consequentemente, como espécie de remédio para a crise de lentidão do processo e da justiça. O CNJ tem se mostrado indutor do aumento cada vez mais intenso da busca da conciliação em todas as esferas do Judiciário. Na Justiça do Trabalho, em especial, os reflexos dessa postura se fazem sentir e tornam evidentes os riscos de uma precarização do direito do trabalho em nome da paz social.

Os riscos, com efeito, são sérios. É premente a necessidade de atenção mais detida ao tema. A cúpula do Judiciário se mostra bastante empolgada com o movimento pela conciliação e seus potenciais efeitos sobre a crise de morosidade. Pudera. A conciliação homologada em primeiro grau de jurisdição pode representar a supressão das demoradas instruções processuais e da necessidade de julgamento do feito pelo juiz. Além disso, suprime a possibilidade de recursos (o termo de conciliação tem força de decisão irrecorrível) e permite às instâncias superiores acalentar o sonho de verem reduzidos a níveis aceitáveis os estoques de recursos pendentes de julgamento.

No entanto, em meio a tanta empolgação, não parece factível uma reflexão mais profunda sobre os limites da conciliação e de suas vantagens, no seio do próprio Poder Judiciário. Evidentemente, no cenário que aqui exponho, todos os esforços são concentrados em atos que a um só tempo divulguem as vantagens da conciliação e silenciem sobre eventuais desvantagens ou riscos. Não há lugar, em tal contexto, para os freios decorrentes de indagações e desconfianças sobre efeitos colaterais do remédio da conciliação, o qual vem sendo receitado universalmente. 
Se, porém, no Judiciário se mostra reduzido o espaço de debates aprofundados sobre os riscos do fomento irrefletido à conciliação, a comunidade acadêmica deve reconhecer a relevância de tais debates. Cumpre, de fato, à ciência a tarefa de qualificar a análise das possibilidades e riscos envolvidos nas campanhas de conciliação, notadamente no que diz respeito ao direito do trabalho. A ciência poderá apontar tendências, limites e propostas para evitar a precarização do direito do trabalho nas mesas de conciliação, até porque, se não o fizer, não há motivos para prever que o próprio Judiciário estimule pesquisas e análises qualitativas sobre esse tema. Não no contexto de crise institucional para cuja solução se crê imprescindível a ampliação da incidência da conciliação.

Ademais, existe o risco de uma flexibilização não declarada, por assim dizer. Nas últimas décadas, travaram-se no Brasil debates acerca da necessidade de tornar a legislação do trabalho mais maleável, no sentido de facilitar a vida do empresário na busca de redução de custos sociais da mão de obra ${ }^{8}$. Mais de uma vez, e por mais de uma forma, se buscou atingir a concretização da máxima do "negociado sobre o legislado", isto é, da liberdade de convenção das partes sobre os direitos a observar no contrato de trabalho ${ }^{9}$. Apesar desses esforços, o direito do trabalho brasileiro, ao menos da perspectiva normativa, não sucumbiu e manteve seu caráter cogente e fundamental; manteve-se como patamar mínimo de garantia social, acima do qual é livre a negociação das partes, inclusive coletivamente, para acrescer direitos e sedimentar a melhoria da condição social dos trabalhadores. Entretanto, aqui se materializa um dos riscos da conciliação irrefletida: o de servir como instrumento de precarização à margem da fiscalização normativa. Dito de outro modo, a conciliação pode eventualmente se tornar o meio perfeito de reduzir o patamar de garantia dos direitos dos trabalhadores, pois com ela o empresariado atingiria a redução de custos de

\footnotetext{
${ }^{8}$ Nas palavras de Márcio Túlio Viana, "[hoje], tanto quanto os objetos que vai produzindo, a empresa quer ser volátil, inconstante, versátil. Quer se apresentar magra, ágil, leve, livre - reproduzindo, talvez, o estereótipo contemporâneo do corpo feminino. Isso lhe permite reduzir não só os custos, mas os riscos, reagindo mais facilmente às variações do mercado. No novo modelo de produção, a forma animal que melhor a representa já não é a do elefante, nem exatamente a do camundongo - mas a do camaleão, animal pequeno, ágil e ao mesmo tempo imprevisível e mutante.” (2017, p. 36).

${ }^{9}$ Ao tempo da conclusão deste texto, entrou em vigor a Lei 13.467/2017, publicada em 13 de julho de 2017, que veiculou a chamada reforma trabalhista, e trouxe alterações na Consolidação das Leis do Trabalho, principalmente no tocante à prevalência da negociação das partes sobre matéria legislada, em alguns âmbitos do contrato de trabalho. Um tópico do desenvolvimento do texto (item 4.4) foi reservado para, ainda que brevemente, analisar algumas das alterações legislativas.
} 
mão de obra sem qualquer afetação da legislação trabalhista ou, muito menos, das normas constitucionais que dão a muitos direitos trabalhistas o status de direitos fundamentais. Enfim, se não foi possível suprimir direitos trabalhistas pela via normativa, mantém-se intacta a normatividade dos direitos, mas concretamente a conciliação poderia atuar na supressão dos mesmos direitos, sob a chancela da homologação estatal.

Tal discurso não encontraria legitimação constitucional. Não há como defendê-lo no ambiente normativo atual. A defesa da conciliação é feita sobre as mesmas bases constitucionais em que se funda o próprio direito do trabalho como mínimo de garantia social. Logo, a conciliação não pode servir como meio de supressão de direitos - essa proposição parece irrefutável, do ponto de vista teórico e dogmático. Por isso, cresce ainda mais a importância da participação da comunidade acadêmica nesse debate. Sim, porque até mesmo para defender, racional e legitimamente, a conciliação é imprescindível a análise qualitativa desse fenômeno.

Justifico, portanto, a escolha do tema desta pesquisa com a necessidade de tratamento claro e direto do assunto relativo à conciliação trabalhista, que vem permanecendo submerso em meio ao desespero a que a crise de lentidão do Judiciário nos conduziu.

\subsection{Contribuição original à ciência jurídica brasileira}

Na linha do que vem sendo exposto, a conclusão inarredável é a de que a ciência jurídica deve propiciar o aprofundamento do debate acerca da conciliação judicial no direito do trabalho. Resgatar a relevância do princípio da irrenunciabilidade e da noção dos direitos dos trabalhadores como direitos fundamentais, de modo a evitar que a conciliação judicial seja (ou possa ser usada como) um meio de precarização do próprio direito do trabalho. Cabe, assim, à comunidade acadêmica conduzir a reflexão por um caminho mais racional e menos apaixonado do que aquele pelo qual trilha o incentivo vindo do comando do Judiciário nacional. 
Eis o objetivo desta pesquisa.

A abordagem parte do pressuposto do caráter fundamental do direito do trabalho, do princípio da irrenunciabilidade e seu conteúdo jurídico e, de outro lado, do conteúdo da conciliação judicial que vem sendo estimulada no país. A hipótese básica do trabalho é o efeito de precarização das condições do trabalho subordinado, causado pela amplitude que está sendo conferida à conciliação judicial como meio de solução dos litígios. Ainda, é interessante saber se é possível, juridicamente, eliminar esse suposto efeito de precarização no uso da conciliação no âmbito do direito do trabalho. Em caso afirmativo, resta a necessidade de investigar como e em quais situações isso seria possível.

Por fim, é possível vislumbrar ainda uma última hipótese: a inconveniência do estímulo institucional à conciliação, do ponto de vista da própria estrutura judiciária do país. Por outras palavras, apesar da crença geral de que seria uma contribuição para a melhoria dos serviços de prestação de justiça no Brasil, permito-me questionar se o estímulo indiscriminado à conciliação em litígios trabalhistas não contribuiria justamente para o resultado contrário. Se o mecanismo da conciliação, em perspectiva estrutural, servir para a redução dos custos sociais dos empregadores (o que ocorreria, de fato, com a precarização decorrente do cumprimento parcial de direitos fundamentais dos trabalhadores), é natural esperar que boa parte dos empresários sinta-se tentada a tornar-se "cliente" da Justiça do Trabalho, isto é, a entrar no grupo dos chamados litigantes habituais. Isso porque a resolução das reclamações dos trabalhadores por um acordo judicial pode se mostrar mais barata que o cumprimento espontâneo e tempestivo dos direitos reclamados. Ora, a partir do momento em que são aceitos e homologados acordos que envolvam transações de direitos como férias, décimo terceiro salário, FGTS e aviso prévio (todos com previsão na Constituição Federal), a Justiça do Trabalho sinaliza um verdadeiro chamado para que as empresas descumpram os direitos e venham ao processo negociar acordos com os empregados e ex-empregados. Dito de outro modo, não estaria a Justiça do Trabalho, com o intuito de reduzir o volume de processos hoje em dia, atuando fortemente na tendência de aumentá-lo em médio e longo prazo? 
Nessa esteira, a pesquisa se orienta pelo ideal de alcançar respostas concretas às hipóteses acima descritas, respostas essas que, sistematizadas, representariam a efetiva contribuição com a ciência jurídica brasileira no campo do saber em exame.

\subsection{Principais questões a ser analisadas}

O trabalho foi estruturado em um total de seis capítulos, contando-se o primeiro, destinado às considerações iniciais, e o último, destinado às considerações finais.

Pois bem. O segundo capítulo tem o objetivo de expor a situação do poder judiciário brasileiro, no contexto da crise que o assola já há alguns anos. A lentidão no julgamento dos processos, como resultado de um número considerado excessivo de ações judiciais, é constatada em dados estatísticos, obtidos pela pesquisa oficial exposta no relatório Justiça em Números, publicado pelo próprio CNJ. Proponho uma análise acerca das causas da crise do judiciário, inclusive questionando a proposição deveras repetida de que a sociedade brasileira estaria exagerando na propositura de ações judiciais. Ainda nesse capítulo, exporei uma análise crítica do chamado Movimento Nacional pela Conciliação, que tem sido usado como meio de concretizar a política de valorização da conciliação no Brasil; e, por fim, uma análise sobre a crise do judiciário voltada especificamente à Justiça do Trabalho, com suas particularidades no tocante à indicação das prováveis causas do número considerável de ações em tramitação.

O terceiro capítulo destina-se a abordar a relação entre o instituto da conciliação judicial e o direito do trabalho no Brasil. Teremos uma visão sobre a tradição da Justiça do Trabalho no tocante à solução negociada dos conflitos, à luz das circunstâncias históricas do surgimento desse ramo do judiciário entre nós. Além disso, no decorrer desse mesmo capítulo, proponho uma análise crítica do discurso de efetividade da tutela jurisdicional fundada na solução conciliada do litígio. Ainda no afã de compreender melhor a relação entre a conciliação e a Justiça do Trabalho brasileira, o capítulo abrange uma exposição histórica do surgimento e implementação dos direitos 
trabalhistas no Brasil, bem como a análise de dados concretos sobre a prática conciliatória no âmbito dos juízos trabalhistas de primeira instância.

Por sua vez, o quarto capítulo expõe as contradições que a prática da conciliação enseja no âmbito dogmático do direito do trabalho. Assim, no plano do direito em si, procuro analisar os desencontros do instituto da conciliação com os princípios basilares do direito do trabalho, notadamente o da irrenunciabilidade. $\mathrm{Na}$ sequência, passo à análise do direito do trabalho como limite da exploração capitalista do trabalho humano, na linha da constituição e objetivos da Organização Internacional do Trabalho (OIT). No bojo desse mesmo capítulo, um item é destinado a analisar criticamente o discurso sobre os benefícios da conciliação aos objetivos de redução de número de processos trabalhistas no país.

Encerrando o capítulo quarto, proponho uma rápida visão sobre a chamada reforma trabalhista de 2017, veiculada pela Lei 13.467/2017. Algumas das inovações trazidas pelo legislador - as que considerei mais pertinentes ao objeto deste trabalho são descritas e submetidas a um olhar crítico, de modo a revelar seus efeitos diretos sobre a dinâmica das conciliações trabalhistas a partir da vigência das alterações legais.

O capítulo quinto (que antecede as considerações finais) é reservado a uma abordagem que não se contém nos estritos limites da dogmática jurídica. Não obstante ser este um trabalho eminentemente jurídico, vários textos filosóficos e algumas reflexões sobre as contradições propriamente jurídicas da conciliação trabalhista me levaram a sentir a necessidade de aprofundar a análise do instituto da conciliação, até chegar a um plano mais profundo, situado além das fronteiras do fenômeno jurídico. Como resultado dessas investigações, esse capítulo inclui a descrição da chamada forma mercadoria e sua influência no funcionamento da sociedade capitalista e, consequentemente, na dinâmica do direito e da própria conciliação trabalhista. Inclui, também, a descrição da forma jurídica estatal, que completa o núcleo fundamental das formas sociais do capitalismo ligadas à dinâmica das conciliações. E ainda, na perspectiva gerada pelo estudo dessas formas sociais, proponho uma visão dos elementos ideológicos que fortalecem a pressão sobre as partes para que se disponham à conciliação. 
$\mathrm{Na}$ parte final do capítulo quinto, chegamos ao ponto de tentar responder aos questionamentos derivados da hipótese fundamental deste trabalho: seria, ou não, a conciliação trabalhista uma maneira de impor à classe trabalhadora uma precarização homologada das suas condições laborais? 


\section{Considerações finais}

Para encerrar este trabalho, apresento aqui uma espécie de fechamento, ou seja, um reencontro com os problemas que nos moveram até a fase final da pesquisa, e a tentativa de lhes oferecer uma proposta de solução.

Ressalvo que não pretendo, de forma alguma, expressar supostas verdades absolutas ou mesmo cristalizar respostas imutáveis. $\mathrm{Na}$ área de conhecimento em que se encaixa esta pesquisa, não há lugar para conclusões imutáveis. Aliás, essa afirmação provavelmente se aplica à maioria - se não à totalidade - das ciências. A conclusão de uma pesquisa representa um retrato, inserido em circunstâncias de tempo e lugar, do conhecimento obtido. E nada mais é do que um ponto de partida para novas pesquisas, que virão a confirmar, ampliar ou modificar os resultados até então conhecidos. $\mathrm{O}$ avanço da ciência requer essa visualização: chega-se a um resultado para fazê-lo degrau do caminho destinado a obter novo progresso. Ciência não combina com dogmas.

A primeira conclusão a salientar é a de que, nos moldes em que vem sendo praticada, a conciliação trabalhista tem o efeito de precarizar as relações de emprego no país. A conciliação, nessa proposição, é pensada em âmbito coletivo e estrutural, exatamente no sentido da política pública adotada pelo Poder Judiciário nacional. É a conciliação estimulada como meio preferencial para a solução de todo e qualquer litígio que seja apresentado à Justiça do Trabalho. Como dito antes, a conciliação em um prisma individual e isolado tem chances de resolver com justiça a lide trabalhista, considerada especificamente. Todavia, a generalização dessa ideia para todos os casos, com campanhas de conciliação em todo o território nacional, e com estímulos de várias ordens às partes, aos advogados e principalmente aos juízes, implica a tendência clara de redução de direitos concretos da classe trabalhadora. Apesar de os textos normativos preverem direitos em um determinado patamar, na realidade forense a incidência da conciliação de forma genérica impõe uma tendência de perda de parte dos direitos previstos. Daí a ideia de precarização homologada. 
Em sendo assim, a política estabelecida pela cúpula do Judiciário não tem amparo constitucional, pois a Constituição Federal estipula claramente o sentido da melhoria da condição social dos trabalhadores, e não prevê nenhuma situação que importe adoção do caminho contrário. O Estado brasileiro tem, portanto, a obrigação constitucional de agir no sentido da melhoria da condição dos trabalhadores, em relação ao patamar que foi previsto pelo próprio constituinte. Na pior das hipóteses, não sendo possível a melhoria, o patamar atual - isto é, o indicado pela Constituição Federal de 1988 - é o mínimo que a sociedade brasileira admite. É o limite mínimo de direitos. É inadmissível, portanto, o retrocesso dos direitos sociais alcançados pela classe trabalhadora.

Tal dever precisa ser observado inclusive pela cúpula do Poder Judiciário, ao elaborar as políticas com as quais pretende equacionar a crise enfrentada pela justiça. Se a política gestada não atende aos preceitos constitucionais aplicáveis, ela simplesmente não deve ser mantida.

O argumento de que a crise propicia legitimidade para a adoção da política de conciliação generalizada não se sustenta. Isso porque as regras constitucionais dirigem-se aos poderes constituídos, mesmo - e principalmente - em épocas de crise.

Então, a legitimidade da política de valorização da conciliação passa necessariamente pela demonstração de que ela não implicaria precarização dos direitos dos trabalhadores. E, como visto durante o desenvolvimento desta tese, tal política não passa por esse filtro. A precarização é um efeito esperado da generalização da conciliação no âmbito do direito do trabalho. E isso é motivo mais do que suficiente para a mudança de foco e para a busca de uma nova forma de enfrentar a propalada crise do Judiciário.

Ainda que pudéssemos compor conjecturas sobre a possibilidade de redução do patamar de direitos sociais em caso de crise, outra conclusão a salientar é a de que a generalização da conciliação não entrega o resultado supostamente prometido à sociedade. Em uma década de movimento pela conciliação, o número de processos judiciais não teve redução; a taxa de congestionamento não teve redução; os prazos de 
julgamento das ações trabalhistas não tiveram melhora significativa. Não é possível imputar ao movimento pela conciliação um resultado efetivo. Não devemos, portanto, por mais essa razão, pensar que investir recursos e esforços na valorização da conciliação irá melhorar o desempenho da Justiça do Trabalho e reduzir os estoques de processos. Em suma, a campanha de conciliação gera precarização dos direitos dos trabalhadores sem obter o benefício coletivo a que se propõe. O fim, definitivamente, não justifica o meio.

A outra questão que deve ser encaminhada é se, com medidas corretivas de qualquer ordem, a conciliação poderia ser adaptada aos interesses sociais da nação. Isto é, se seria possível "consertar" a conciliação praticada no Brasil, de modo a torná-la adequada aos preceitos da Constituição Federal.

Com relação a esse problema, duas abordagens diferentes são necessárias. Em primeiro lugar, pensemos na conciliação individualizada e específica, atenta às circunstâncias de cada caso concreto e às suas peculiaridades não estruturais. Quanto a essa aplicação da conciliação, é correto dizer que ela pode ser legitimada com medidas que, a rigor, nada têm de complexas. Bastaria, como vimos, a aplicação concreta do princípio da irrenunciabilidade dos direitos pelo trabalhador, a vedação da cláusula de quitação geral dos direitos do contrato de trabalho, e a verificação cuidadosa dos benefícios perseguidos pelas partes na realização do acordo.

Parece simples. E de fato é, já que se trata de mera aplicação do direito posto. Porém, a adoção de medidas desse jaez reduziria muito o interesse do empregador na formalização do acordo. Os acordos seriam homologados pontualmente, mais em varejo do que em atacado, digamos assim. Daí por que saliento que esse tipo de conciliação seria pontual, individualizado, e até mesmo tolerado - em vez de estimulado. É a conciliação artesanal, construída específica e adequadamente para o caso concreto, e não generalizada e abstrata, imposta como solução para a totalidade dos litígios, em ritmo de produção de acordos em série.

A segunda abordagem para o problema é aquela que se refere justamente à conciliação vista como política pública, estimulada e generalizada como solução 
preferencial para todos os litígios trabalhistas. Nesse plano estrutural do problema, a conclusão só pode ser a de que é impossível "consertar" juridicamente a conciliação.

Conforme a exposição realizada no decorrer do capítulo 5, aqui o problema diz respeito à própria forma em que se desenvolve a valorização da conciliação trabalhista. Tendo em vista que o plano jurídico e o plano político estatal refletem a forma básica da reprodução da sociedade capitalista - a forma mercantil -, a dinâmica da conciliação atua no sentido do favorecimento da acumulação do capital, que é o sentido da forma mercantil. A lógica mercantil na negociação generalizada de acordos impõe a tendência de exploração do trabalhador - aliás, mais uma exploração, pois ela já ocorrera no momento da prestação do trabalho. É a lógica da operação de compra e venda aplicada aos direitos do trabalhador, operação da qual o capital está talhado a obter vantagem.

Assim, a impossibilidade de a conciliação colaborar na melhoria da condição social dos trabalhadores, no plano estrutural, decorre da impossibilidade de lhe atribuir uma dinâmica que não coincida com a dinâmica da forma-mercadoria. A conciliação é praticada como política pelo Poder Judiciário; este materializa a forma política estatal; esta por sua vez deriva da forma-mercadoria e garante a circulação das mercadorias e, consequentemente, a acumulação do capital. Ora, se a conciliação é apresentada pela mesma estrutura responsável pela garantia da acumulação do capital, ela logicamente favorecerá a exploração do trabalho. Não há como inverter esse ciclo, dentro da lógica mercantil.

Nesses termos, os trabalhadores, como classe, assistem à precarização de seus direitos no plano da conciliação generalizada. Resta-lhes, tanto no sentido jurídico quanto no sentido político, a luta. 


\section{Referências bibliográficas}

AGUIAR, André Luiz Souza. Assédio moral: o direito à indenização pelos maustratos e humilhações sofridos no ambiente do trabalho. 2 ed. São Paulo: LTr, 2006.

ALMEIDA, Frederico Normanha Ribeiro de. A nobreza togada - as elites jurídicas e a política da justiça no Brasil. Tese de doutorado. São Paulo: FFLCH-USP, 2010.

ALVES, Alaor Caffé. Estado e ideologia: aparência e realidade. São Paulo: Brasiliense, 1987.

ALVES, Giovanni. “As condições de produção da Justiça do Trabalho no Brasil: uma análise crítica do documentário 'O trabalho do juiz'”. In: ALVES, Giovanni (org). O trabalho do juiz. Bauru: Canal 6, 2014.

ALTHUSSER, Louis. "Ideologia e aparelhos ideológicos do estado (notas para uma investigação)". In: ZIZEK, Slavoj (org). Um mapa da ideologia. Tradução Vera Ribeiro. Rio de Janeiro: Contraponto, 1996.

ANTUNES, Ricardo. Os sentidos do trabalho: ensaio sobre a afirmação e a negação do trabalho. São Paulo: Boitempo, 1999.

O caracol e sua concha: ensaios sobre a nova morfologia do trabalho. São Paulo: Boitempo, 2005.

O continente do labor. São Paulo: Boitempo, 2011.

Adeus ao trabalho? Ensaio sobre as metamorfoses e a centralidade do mundo do trabalho. 16 ed. São Paulo: Cortez, 2015.

ASSIS, Luís Fabiano de. "Transação e renúncia no direito do trabalho e seus reflexos no direito processual do trabalho". In: THOME, Candy Florêncio. SCHWARZ, Rodrigo Garcia (orgs). Direito processual do trabalho: curso de revisão e atualização. Rio de Janeiro: Elsevier, 2011. 
ÁVILA, Humberto Bergman. Teoria dos princípios: da definição à aplicação dos princípios jurídicos. 12 ed. São Paulo: Malheiros, 2011.

BACELLAR, Roberto Portugal. "O Poder Judiciário e o paradigma da guerra na solução de conflitos". In: PELUSO, Antônio Cezar; RICHA, Morgana de Almeida (orgs). Conciliação e mediação: estruturação da política judiciária nacional. Rio de Janeiro: Forense, 2011.

BALDINI, Renato Ornellas. "O combate do dumping social na União Europeia e a harmonização de normas". In: BELTRAN, Ari Possidonio (coord.). A União Europeia e o direito do trabalho. São Paulo: LTr, 2012.

BARBOSA, Rui. Oração aos moços. Coletânea Mestre Rui Barbosa. 5 ed. Brasília: Caixa, 2015.

BARCELLOS, Ana Paula de. Ponderação, racionalidade e atividade jurisdicional. Rio de Janeiro: Renovar, 2005.

BARRETO, Margarida. Violência, saúde e trabalho: uma jornada de humilhações. São Paulo: EDUC, 2006.

BARROS, Alice Monteiro de. Curso de direito do trabalho. 11 ed. São Paulo: LTr, 2017.

BATALHA, Wilson de Souza Campos. Tratado de direito judiciário do trabalho. 3 ed. São Paulo: LTr, 1995.

BATISTA, Flávio Roberto. Crítica da tecnologia dos direitos sociais. Tese de doutorado. São Paulo: FD-USP, 2012.

BATTAGLIA, Felice. Filosofia do trabalho. São Paulo: Saraiva, 1958.

BEBBER, Júlio César. Princípios do processo do trabalho. São Paulo: LTr, 1997.

2011.

Processo do trabalho: adaptação à contemporaneidade. São Paulo: LTr,

BEDAQUE, José Roberto dos Santos. Efetividade do processo e técnica processual. 2 ed. São Paulo: Malheiros, 2007.

BELTRAN, Ari Possidonio. Direito do Trabalho e Direitos Fundamentais. São Paulo: LTr, 2002.

BERCOVICI, Gilberto. Constituição econômica e desenvolvimento: uma leitura a partir da Constituição de 1988. São Paulo: Malheiros, 2005.

; MASSONETO, Luís Fernando. "Breve história da incorporação dos direitos sociais nas constituições democráticas brasileiras". Revista do Departamento de Direito do Trabalho e da Seguridade Social da USP. São Paulo, v. 2, n. 3, janeiro/junho 2007. 
BIAVASCHI, Magda Barros. O direito do trabalho no Brasil - 1930 a 1942: a construção do sujeito de direitos trabalhistas. São Paulo: LTr, Justra - Associação Lusobrasileira de Juristas do Trabalho, 2007.

. "Direito e Justiça do Trabalho no Brasil: notas sobre uma trajetória com bem mais de 70 anos". Revista do TST. Brasília, v. 77, n. 2. abril/junho 2011.

. "A construção e os fundamentos do direito do trabalho no Brasil". Revista do Advogado. São Paulo, ano 33, n. 121. novembro/2013.

BITTAR, Carlos Alberto. "A missão do juiz no processo moderno". Revista dos Tribunais, ano 83, v. 704, junho/1994, p. 265-267.

BOBBIO, Norberto. A Era dos Direitos. Tradução de Carlos Nelson Coutinho. Nova edição. 10 reimpressão. Rio de Janeiro: Editora Elsevier, 2004.

BONAVIDES, Paulo. Curso de direito constitucional. 13 ed. São Paulo: Malheiros, 2003.

Do estado liberal ao estado social. 9 ed. São Paulo: Malheiros, 2009.

BOSI, Alfredo. Ideologia e contraideologia: temas e variações. São Paulo: Companhia das Letras, 2010.

BRANCO, Ana Paula Tauceda. A colisão de princípios constitucionais no direito do trabalho. São Paulo: LTr, 2007.

BRASIL. Conselho Nacional de Justiça. Justiça em números 2016 - ano base 2015. Brasília: CNJ, 2016.

BRASIL. Conselho Nacional de Justiça. Justiça em números 2017 - ano base 2016. Brasília: CNJ, 2017.

BRASIL. Tribunal Superior do Trabalho. Relatório Geral da Justiça do Trabalho 2016. Brasília: TST, 2017.

CANOTILHO, José Joaquim Gomes. Direito constitucional e teoria da constituição. 7 ed. Coimbra: Almedina, 2003.

CAPPELlETTI, Mauro. GARTH, Bryant. Acesso à justiça. Trad. Ellen Gracie Northfleet. Porto Alegre: Sergio Antonio Fabris Editor, 1988.

CARVALHO, Amilton Bueno de. "A lei, o juiz, o justo". Revista Ajuris. Porto Alegre, ano XIV, v. 39, março 1987.

. "Flexibilização vs direito alternativo". Lições de direito alternativo do trabalho. São Paulo: Acadêmica, 1993. 
. "A questão da lei ou da justiça: da esquizofrenia, da legalidade ao império da cidadania". Labor e Justitia - Revista do TRT da $17^{\text {a }}$ Região. Vitória. V. 1, n. 2. janeiro/junho 1998.

CARVALHO, Augusto César Leite de. Direito do trabalho: curso e discurso. São Paulo: LTr, 2016.

CASTELANI, Sérgio André. Reclamações trabalhistas e eficiência econômica. Dissertação de Mestrado. São Paulo: FEA-USP, 2008.

CESARINO JÚNIOR, Antônio Ferreira. Direito social brasileiro. São Paulo: LTr, 1980.

CHAUÍ, Marilena. Brasil: mito fundador e sociedade autoritária. São Paulo: Fundação Perseu Abramo, 2000.

O que é ideologia. 2 ed. São Paulo: Brasiliense, 2008.

CHIOVENDA, Giuseppe. Instituições de direito processual civil: as relações processuais, a relação processual ordinária de cognição. V. 1. Campinas: Bookseller, 1998.

CINTRA, Antônio Carlos de Araújo. DINAMARCO, Cândido Rangel. GRINOVER, Ada Pellegrini. Teoria geral do processo. 10 ed. São Paulo: Malheiros, 1994.

COMPARATO, Fábio Konder. A afirmação histórica dos direitos humanos. 8 ed. São Paulo: Saraiva, 2013.

COSTA, Coqueijo. Direito judiciário do trabalho. Rio de Janeiro: Forense, 1978.

COSTA, Emília Viotti da. Da senzala à colônia. 5 ed. São Paulo: UNESP, 2010.

COSTA, Orlando Teixeira da. "Reflexões preliminares sobre a renúncia e a transação num processo de flexibilização laboral”. Revista do Tribunal Superior do Trabalho. 1991.

COTTERRELL, Roger. "Forma mercantil e forma jurídica: Pachukanis e o esboço de uma teoria materialista do direito”. In: NAVES, Márcio Bilharinho Naves (org). O discreto charme do direito burguês: ensaios sobre Pachukanis. Campinas: Unicamp, 2009.

COUTINHO, Grijalbo Fernandes. O direito do trabalho flexibilizado por FHC e Lula. São Paulo: LTr, 2009.

CUNHA, Rodrigo Giostri da. O processo do trabalho como instrumento de efetivação dos direitos sociais trabalhistas: contribuições para o aprimoramento da prestação jurisdicional trabalhista. Dissertação de Mestrado. São Paulo: FD-USP, 2008. 
DAL ROSSO, Sadi. Mais trabalho!: a intensificação do labor na sociedade contemporânea. São Paulo: Boitempo, 2008.

DALLARI, Dalmo de Abreu. O poder dos juízes. 3 ed. São Paulo: Saraiva, 2007.

DALLEGRAVE NETO, José Affonso. Responsabilidade civil no direito do trabalho. 3 ed. São Paulo: LTr, 2008.

DE LA CUEVA, Mario. Derecho mexicano del trabajo. 4 ed. México: Porrúa, 1954.

DELGADO, Maurício Godinho. "Arbitragem, mediação e comissão de conciliação prévia no direito do trabalho brasileiro". Revista LTr. São Paulo, v. 66, n. 6, junho 2002.

Curso de direito do trabalho. 4 ed. São Paulo: LTr, 2005.

; DELGADO, Gabriela Neves. A reforma trabalhista no Brasil: com os comentários à Lei n. 13.467/2017. São Paulo: LTr, 2017.

DEMARCHI, Juliana. Mediação: proposta de implementação no processo civil brasileiro. Tese de Doutorado. São Paulo: FD-USP, 2007.

DIMOULIS, Dimitri. MARTINS, Leonardo. Teoria geral dos direitos fundamentais. 3 ed. São Paulo: RT, 2011.

DINAMARCO, Cândido Rangel. A instrumentalidade do processo. 15 ed. São Paulo: Malheiros, 2013.

DUBUGRAS, Regina Maria Vasconcelos. "A conciliação e a mediação na Justiça do Trabalho: conciliação qualificada". Revista do Advogado. São Paulo, ano 34, n. 123, agosto 2014.

EAGLETON, Terry. Ideologia: uma introdução. Tradução Luis Carlos Borges e Silvana Vieira. São Paulo: Boitempo-Unesp, 1997.

ECO, Umberto. Como se faz uma tese. Tradução Ana Falcão Bastos e Luís Leitão. 13 ed. Lisboa: Editorial Presença, 2007.

EDELMAN, Bernard. A legalização da classe operária. Trad. Marcus Orione Gonçalves Correia. São Paulo: Boitempo, 2016.

ENGELS, Friedrich. A situação da classe trabalhadora na Inglaterra. Tradução B. A. Schumann; supervisão, apresentação e notas José Paulo Netto. São Paulo: Boitempo, 2010.

; KAUTSKY, Karl. Socialismo jurídico. Tradução Lívia Cotrim e Marcio Bilharinho Naves. São Paulo: Boitempo, 2012. 
FAVA, Marcos Neves. "Comissões de conciliação prévia e crime de frustração de direito trabalhista". In: Jornal Magistratura e Trabalho. São Paulo, ano 11, n. 43, p. 8-9, fevereiro/março 2002.

. "A arbitragem como meio de solução dos conflitos trabalhistas". In: Revista de Direito do Trabalho. São Paulo, ano 32, n. 123, p. 120-142, julho/setembro 2006.

. Ação civil pública trabalhista: teoria geral. 2 ed. São Paulo: LTr, 2008.

Execução trabalhista efetiva. São Paulo: LTr, 2009.

FELICIANO, Guilherme Guimarães. "Tutela processual dos direitos humanos nas relações de trabalho". Jus Navigandi. Teresina, ano 10, n. 910, dezembro 2005. Disponível em http://jus2.uol.com.br/doutrina/texto.asp?id=7810.

(coord.). Fênix: por um novo processo do trabalho. São Paulo: LTr, 2011.

Curso crítico de direito do trabalho: teoria geral do direito do trabalho. São Paulo: Saraiva, 2013.

FERRARI, Irany. NASCIMENTO, Amauri Mascaro. MARTINS FILHO, Ives Gandra da Silva. História do trabalho, do direito do trabalho e da Justiça do Trabalho. 3 ed. São Paulo: LTr, 2011.

FILGUEIRAS, Vítor Araújo. Estado e direito do trabalho no Brasil: regulação do emprego entre 1988 e 2008. Tese de doutorado. Salvador: UFBA, 2012.

FISS, Owen. Um novo processo civil - Estudos norte-americanos sobre jurisdição, constituição e sociedade. Tradução Daniel Porto Godinho da Silva e Melina de Medeiros Rós. Coordenação de tradução Carlos Alberto de Salles. São Paulo: Revista dos Tribunais, 2004.

GABBAY, Daniela Monteiro. Mediação e judiciário: condições necessárias para a institucionalização dos meios autocompositivos de solução de conflitos. Tese de Doutorado. São Paulo: FD-USP, 2011.

GIANNOTTI, Vito. História das lutas dos trabalhadores no Brasil. Rio de Janeiro: Mauad X, 2007.

GIGLIO, Wagner Drdla. “A crise da Justiça do Trabalho". Revista do TRT 8a Região. Belém. V. 16, n. 30. janeiro/junho 1983.

Síntese, 1997.

A conciliação nos dissídios individuais do trabalho. 2 ed. Porto Alegre: Direito processual do trabalho. 16 ed. São Paulo: Saraiva, 2007.

GOMES, Orlando. GOTTSCHALK, Élson. Curso de direito do trabalho. 18 ed. Rio de Janeiro: Forense, 2008. 
GONÇALVES, Leandro Krebs. "Conciliação judicial trabalhista: transação ou renúncia?" In: THOME, Candy Florêncio. SCHWARZ, Rodrigo Garcia (orgs). Direito processual do trabalho: curso de revisão e atualização. Rio de Janeiro: Elsevier, 2011.

GOSDAL, Thereza Cristina. SOBOLL, Lis Andrea Pereira (org.). Assédio moral interpessoal e organizacional: um enfoque interdisciplinar. São Paulo: LTr, 2009.

GRAU, Eros Roberto. O direito posto e o direito pressuposto. 7 ed. São Paulo: Malheiros, 2008.

Por que tenho medo dos juízes (a interpretação/aplicação do direito e os princípios). São Paulo: Malheiros, 2014.

GUAMÁN-HERNÁNDEZ, Adoración. "Dumping social". In: BAYLOS GRAU, Antonio; THOMÉ, Candy Florêncio; SCHWARZ, Rodrigo Garcia (coordenadores). Diccionario internacional de derecho del trabajo e de la seguridad social. Valencia: Tirant Lo Blanch, 2014.

HILLESHEIM, Jaime. Conciliação Trabalhista: ofensiva sobre os direitos dos trabalhadores na periferia do capitalismo. Rio de Janeiro: Lúmen Juris, 2016.

HIRANO, Ana Farias. Acordos homologados pela Justiça do Trabalho: uma análise dos dissídios individuais na fase de conhecimento. Dissertação de Mestrado. São Paulo: FD-USP, 2008.

HIRSCH, Joachim. Teoria materialista do estado. Tradução Luciano Cavini Martorano. Rio de Janeiro: Revan, 2010.

HOBSBAWM, Eric. Mundos do trabalho: novos estudos sobre a história operária. Tradução Waldea Barcellos e Sandra Bedran. 6 ed. São Paulo: Paz e Terra, 2015.

HUBERMAN, Leo. História da riqueza do homem. Tradução de Waltensir Dutra. Rio de Janeiro: Zahar, 1974.

IHERING, Rudolf Von. A luta pelo direito. Rio de Janeiro: Forense, 1997.

JAPIASSU, Hilton. O mito da neutralidade científica. Rio de Janeiro: Imago, 1975.

JAVILLIER, Jean-Claude. Manual de direito do trabalho. Tradução de Rita Asdine Bozaciyan. São Paulo: LTr, 1988.

KASHIURA JÚNIOR, Celso Naoto. Sujeito de direito e capitalismo. São Paulo: Outras Expressões/Dobra Universitária, 2014.

KONDER, Leandro. A questão da ideologia. São Paulo: Companhia das Letras, 2002.

KOWARICK, Lúcio. Trabalho e vadiagem: a origem do trabalho livre no Brasil. 2 ed. Rio de Janeiro: Paz e Terra, 1994. 
LACERDA, Dorval Marcenal de. MORAES FILHO, Evaristo de. (coord). A renúncia no direito do trabalho. Rio de Janeiro: Max Limonad, 194?.

LEITE, Carlos Henrique Bezerra. Curso de direito processual do trabalho. 3 ed. São Paulo: LTr, 2005.

LESSA, Sérgio; TONET, Ivo. Introdução à filosofia de Marx. 2 ed. São Paulo: Expressão Popular, 2011.

LÖWY, Michael. Ideologias e ciência social: elementos para uma análise marxista. 7. ed., São Paulo: Cortez, 1991.

MACHADO, Gustavo Seferian Scheffer. A ideologia do contrato de trabalho. Dissertação de mestrado. São Paulo: FD-USP, 2012.

MAEDA, Patrícia. A era dos zero direitos: trabalho decente, terceirização e contrato zero-hora. São Paulo: LTr, 2017.

MALLET, Estevão. Direito, trabalho e processo em transformação. São Paulo: LTr, 2005.

MARANHÃO, Délio. Direito do trabalho. 4 ed. Rio de Janeiro: FGV, 1976.

MARCONATTO, Alessandra. "La precarización de las relaciones de trabajo en un mundo globalizado y en crisis". In: SCHWARZ, Rodrigo Garcia; THOME, Candy Florêncio (coordenadores). Estudios hispanoamericanos de derecho del trabajo. São José-Costa Rica: Editorial Jurídica Continental, 2012.

MARINONI, Luiz Guilherme. Curso de processo civil: teoria geral do processo. v. 1. São Paulo: RT, 2006.

MARQUESE, Rafael; SALLES, Ricardo. "A escravidão no Brasil oitocentista: história e historiografia". In: MARQUESE, Rafael; SALLES, Ricardo (orgs). Escravidão e capitalismo histórico no século XIX: Cuba, Brasil, Estados Unidos. Rio de Janeiro: Civilização Brasileira, 2016.

MARX, Karl. Crítica da filosofia do direito de Hegel. Tradução Rubens Enderle e Leonardo de Deus. 2 ed. São Paulo: Boitempo, 2010.

O capital: crítica da economia política: Livro I: o processo de produção do capital. Tradução Rubens Enderle. São Paulo: Boitempo, 2013.

MASCARO, Alysson Leandro. Estado e forma política. São Paulo: Boitempo, 2013.

Filosofia do direito. 4 ed. São Paulo: Atlas, 2014.

MELHADO, Reginaldo. "Comissões de conciliação: a lógica do avesso". Genesis Revista de Direito do Trabalho. Curitiba, n. 87, março 2000. 
Poder e sujeição: os fundamentos da relação de poder entre capital e trabalho e o conceito de subordinação. São Paulo: LTr, 2003.

MELO, Tarso Menezes de. Ambiguidade e resistência: direito, política e ideologia na neoliberalização constitucional. Tese de Doutorado. São Paulo: FD-USP, 2011.

MORAES, Evaristo de. Apontamentos de direito operário. 2 ed. São Paulo: LTr, 1971.

MORAES, Maria Isabel Cueva. "Conciliação em conflitos coletivos de trabalho: a Resolução n. 125 do Conselho Nacional de Justiça e as relações coletivas laborais: experiência do Tribunal Regional do Trabalho da $2^{\text {a }}$ Região: desafios e perspectivas". Revista do Advogado. São Paulo. Ano 34, n. 123, p. 123-128, agosto 2014.

MORAES FILHO, Evaristo de. Tratado elementar de direito do trabalho. Rio de Janeiro: Freitas Bastos, 1960.

1982.

Direito do trabalho: páginas de história e outros ensaios. São Paulo: LTr,

"A filosofia social da legislação do trabalho brasileira". Revista de Direito do Trabalho. São Paulo, ano 11, n. 64, novembro/dezembro 1986.

MOREIRA, José Carlos Barbosa. "Imparcialidade: reflexões sobre a imparcialidade do juiz”. Revista Jurídica Nota Dez. Porto Alegre, ano 46, número 250, agosto 1998.

O novo processo civil brasileiro. 22 ed. Rio de Janeiro: Forense, 2002.

NASCIMENTO, Amauri Mascaro. NASCIMENTO, Sônia Mascaro. Iniciação ao direito do trabalho. 40 ed. São Paulo: LTr, 1999.

NASSIF, Elaine. Conciliação judicial e indisponibilidade de direitos - Paradoxos da “justiça menor" no processo civil e trabalhista. São Paulo: LTr, 2005.

NAVES, Márcio Bilharinho. Marx: ciência e revolução. São Paulo: Moderna, 2000.

2008.

Marxismo e direito: um estudo sobre Pachukanis. São Paulo: Boitempo,

. "Evgeni Bronislavovitch Pachukanis". In: (org). O discreto charme do direito burguês: ensaios sobre Pachukanis. Campinas: Unicamp, 2009.

A questão do direito em Marx. São Paulo: Outras Expressões/Dobra Universitária, 2014.

NOGUEIRA, Otávio Pupo. A indústria em face das leis do trabalho. São Paulo: Escolas Profissionaes Salesianas, 1935. 
OLEA, Manuel Alonso. Introdução ao direito do trabalho. Tradução da 5 ed. espanhola. Tradução de Regina Maria Macedo Nery Ferrari, Aglaé Marcon, Itacir Luchtemberg e Sebastião Antunes Furtado. Curitiba: Genesis, 1997.

OLIVEIRA, Bruno Batista da Costa de. Jurisdição e poder: usos disciplinares dos discursos do processo civil. Curitiba: Juruá, 2015.

OLIVEIRA, Paulo Eduardo Vieira de. $O$ dano pessoal no direito do trabalho. 2 ed. São Paulo: LTr, 2010. LTr, 2013.

Assédio moral no trabalho: caracterização e consequências. São Paulo:

OLIVEIRA, Sebastião Geraldo de. Indenizações por acidente do trabalho ou doença ocupacional. 3 ed. São Paulo: LTr, 2007.

. Proteção jurídica à saúde do trabalhador. 6 ed. São Paulo: LTr, 2011.

PACHÁ, Andrea Maciel. "Movimento pela conciliação - o foco na sociedade." In: PELUSO, Antônio Cezar; RICHA, Morgana de Almeida (orgs). Conciliação e mediação: estruturação da política judiciária nacional. Rio de Janeiro: Forense, 2011.

PACHUKANIS, Evguiéni B. Teoria geral do direito e marxismo. Tradução Silvio Donizete Chagas. São Paulo: Acadêmica, 1988.

Teoria geral do direito e marxismo. Tradução Paula Vaz de Almeida; revisão técnica Alysson Leandro Mascaro e Pedro Davoglio. São Paulo: Boitempo, 2017.

PADILHA, Norma Sueli. Do meio ambiente do trabalho equilibrado. São Paulo: LTr, 2002.

PARANHOS, Adalberto. O roubo da fala: origens da ideologia do trabalhismo no Brasil. 2 ed. São Paulo: Boitempo, 2007.

PASCO, Mario. Fundamentos do direito processual do trabalho. Tradução Edilson Alckimim Cunha. São Paulo: LTr, 1997.

PENA, Martins. O juiz de paz na roça. São Paulo: FTD, 2009.

PESSOA, Flávia Moreira Guimarães. "Reforma trabalhista e a restrição a atuação da Justiça do Trabalho". In: FELICIANO, Guilherme Guimarães; TREVISO, Marco Aurélio Marsiglia; FONTES, Saulo Tarcísio de Carvalho (organizadores). Reforma trabalhista: visão, compreensão e crítica. São Paulo: LTr, 2017.

PIMENTA, José Roberto Freire. "Lides simuladas: a Justiça do Trabalho como órgão homologador". Revista LTr. São Paulo, v. 64, n. 01, janeiro 2000.

PINTO, José Augusto Rodrigues. "Dumping social ou delinquência patronal na relação de emprego?”. Revista do TST. Brasília, v. 77, n. 3, julho/setembro 2011. 
PIOVESAN, Flávia. Direitos Humanos e o Direito Constitucional Internacional. 11 ed. São Paulo: Saraiva, 2010.

PIRES, Líbia da Graça. Teoria da distribuição dinâmica do ônus da prova no processo do trabalho. Tese de Doutorado. São Paulo: FD-USP, 2011.

PLÁ RODRIGUEZ, Américo. Princípios de direito do trabalho. Trad. Wagner Giglio. 3 ed. São Paulo: LTr, 2014.

POCHMANN, Márcio. "Desempregados do Brasil". In: ANTUNES, Ricardo (org). Riqueza e miséria do trabalho no Brasil. São Paulo: Boitempo, 2006.

. A superterceirização do trabalho. São Paulo: LTr, 2008.

PORTANOVA, Rui. Motivações ideológicas da sentença. 5 ed. Porto Alegre: Livraria do Advogado, 2003.

PRADO, Lídia Reis de Almeida. O juiz e a emoção: aspectos da lógica da decisão judicial. 5 ed. Campinas: Millennium, 2010.

PRADO JÚNIOR, Caio. História econômica do Brasil. Atualização de 1970. São Paulo: Brasiliense, 2008.

RAMOS FILHO, Wilson. Direito capitalista do trabalho: história, mitos e perspectivas no Brasil. São Paulo: LTr, 2012.

RIBEIRO, Darcy. O povo brasileiro: a formação e o sentido do Brasil. 3 ed. São Paulo: Global, 2015.

RICHA, Morgana de Almeida. "Evolução da semana nacional de conciliação como consolidação de um movimento nacional permanente da justiça brasileira." In: PELUSO, Antônio Cezar; RICHA, Morgana de Almeida (orgs). Conciliação e mediação: estruturação da política judiciária nacional. Rio de Janeiro: Forense, 2011.

ROMITA, Arion Sayão. Direitos Fundamentais nas Relações de Trabalho. 5 ed. São Paulo: LTr, 2014.

RUSSOMANO, Mozart Victor. Curso de direito do trabalho. 6 ed. Curitiba: Juruá, 1997.

SAES, Décio. A formação do estado burguês no Brasil. 2 ed. Rio de Janeiro: Paz e Terra, 1985.

SANTOS, Boaventura de Sousa. Para uma revolução democrática da justiça. São Paulo: Cortez, 2007. 
SANTOS, Enoque Ribeiro dos. "O dumping social nas relações de trabalho: formas de combate”. Revista do TRT 15ª Região. Campinas, n. 48, janeiro/junho 2016.

SARLET, Ingo Wolfgang. A eficácia dos direitos fundamentais. 6 ed. Porto Alegre: Livraria do Advogado, 2006.

Dignidade da pessoa humana e direitos fundamentais na Constituição Federal de 1988. 8 ed. Porto Alegre: Livraria do Advogado, 2010.

SCHWARZ, Rodrigo Garcia. Los derechos sociales como derechos humanos fundamentales: su imprescindibilidad y sus garantías. México: Porrúa, 2011.

SENA, Adriana Goulart de. "Juízo conciliatório trabalhista". Revista LTr. São Paulo, v. 71, n. 10, outubro 2007.

SEVERO, Valdete Souto. Elementos para o uso transgressor do direito do trabalho: compreendendo as relações sociais de trabalho no Brasil e a função do direito diante das possibilidades de superação da forma capital. São Paulo: LTr, 2016.

; ALMEIDA, Almiro Eduardo de. "Entre o ordenamento jurídico e o costume: o problema da quitação no acordo trabalhista”. Revista LTr. São Paulo, v. 77, n. 8, agosto 2013.

SILVA, Homero Batista Mateus da. Comentários à reforma trabalhista. São Paulo: Revista dos Tribunais, 2017.

SILVA, Otávio Pinto e. "Audiência trabalhista". In: THOME, Candy Florêncio. SCHWARZ, Rodrigo Garcia (orgs). Direito processual do trabalho: curso de revisão e atualização. Rio de Janeiro: Elsevier, 2011.

SILVA, Sayonara Grillo Coutinho Leonardo da. "O direito do trabalho e sua relação com o direito comum entre autonomia, subsidiariedade e confluência: interpretando o art. $8^{\circ}$ da Consolidação Reformada das Leis do Trabalho à luz do particularismo". In: FELICIANO, Guilherme Guimarães; TREVISO, Marco Aurélio Marsiglia; FONTES, Saulo Tarcísio de Carvalho (organizadores). Reforma trabalhista: visão, compreensão e crítica. São Paulo: LTr, 2017.

SILVA, Virgílio Afonso da. Direitos fundamentais: conteúdo essencial, restrições e eficácia. 2 ed. São Paulo: Malheiros, 2010.

SOUTO MAIOR, Jorge Luiz. O direito do trabalho como instrumento de justiça social. São Paulo: LTr, 2000.

Curso de direito do trabalho: teoria geral do direito do trabalho, volume I: parte I. São Paulo: LTr, 2011.

. SEVERO, Valdete Souto. MOREIRA, Ranúlio Mendes. Dumping social nas relações de trabalho. 2 ed. São Paulo: LTr, 2014. 
. História do direito do trabalho no Brasil: curso de direito do trabalho. Volume I: Parte II. São Paulo: LTr, 2017.

STEINMETZ, Wilson. A Vinculação dos Particulares a Direitos Fundamentais. São Paulo: Malheiros, 2004.

SÜSSEKIND, Arnaldo et al. Instituições de direito do trabalho. 22 ed. São Paulo: LTr, 2005.

TEIXEIRA FILHO, Manoel Antonio. Manual da audiência na Justiça do Trabalho. São Paulo: LTr, 2010.

TESTA, Felice. "Clausole anti-dumping sociale nella contrattazione collettiva". Revista do TRT 15ª Região. Campinas, n. 22, janeiro/junho 2003.

TOLEDO FILHO, Manoel Carlos. Fundamentos e perspectivas do processo trabalhista brasileiro. São Paulo: LTr, 2006.

. "O processo do trabalho brasileiro do século XXI". In: LOCKMANN, Ana Paula Pellegrina; GIORDANI, Francisco Alberto da Motta Peixoto (coords). Repercussões no processo do trabalho do CPC de 2015: homenagem ao Desembargador Lorival Ferreira dos Santos. São Paulo: LTr, 2017.

URIARTE, Oscar Ermida. A flexibilidade. São Paulo: LTr, 2002.

VIANA, Márcio Túlio. "Os paradoxos da conciliação: quando a ilusão da igualdade formal esconde mais uma vez a desigualdade real". Revista do Tribunal Regional do

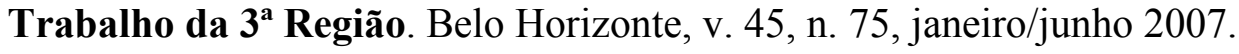

. Para entender a terceirização. 3 ed. São Paulo: LTr, 2017.

WATANABE, Kazuo. "Política pública do Poder Judiciário nacional para tratamento adequado dos conflitos de interesses". In: PELUSO, Antônio Cezar; RICHA, Morgana de Almeida (orgs). Conciliação e mediação: estruturação da política judiciária nacional. Rio de Janeiro: Forense, 2011.

WEIS, Carlos. Os direitos humanos contemporâneos. 2 ed. São Paulo: Malheiros, 2010 .

WILLIAMS, Eric. Capitalismo e escravidão. São Paulo: Companhia das Letras, 2012.

WOLKMER, Antonio Carlos. Ideologia, estado e direito. 4 ed. São Paulo: RT, 2003. 